Article

\title{
Sustainable Campus: Reducing Environmental and Financial Burdens by Using Pruned Branches for On-Campus Energy
}

\author{
Sota Makino ${ }^{1,2}{ }^{\text {, Takeshi Onishi }}{ }^{3}$, Akika Itoh ${ }^{4}$, Issei Sato ${ }^{5}$, Tomohumi Huzita ${ }^{6}$ and Chihiro Kayo ${ }^{7, *}$ \\ 1 Faculty of Agriculture, Tokyo University of Agriculture and Technology, Tokyo 183-8509, Japan; \\ som6.takino18@gmail.com \\ 2 Information System Department, Itochu Kenzai Corporation, Tokyo 103-8419, Japan \\ 3 Hibiya Amenis Corporation, Tokyo 108-0073, Japan; t-onishi@amenis.co.jp \\ 4 Japan Wood Energy Co., Ltd., Tokyo 205-0001, Japan; itoh@mori-energy.jp \\ 5 Graduate School of Agriculture, Tokyo University of Agriculture and Technology, Tokyo 183-8509, Japan; \\ s210576z@st.go.tuat.ac.jp \\ 6 United Graduate School of Agricultural Science, Tokyo University of Agriculture and Technology, \\ Tokyo 183-8509, Japan; s195462r@st.me.tuat.ac.jp \\ 7 Institute of Agriculture, Tokyo University of Agriculture and Technology, Tokyo 183-8509, Japan \\ * Correspondence: kayoc@cc.tuat.ac.jp; Tel.: +81-42-367-5729
}

check for

updates

Citation: Makino, S.; Onishi, T.; Itoh,

A.; Sato, I.; Huzita, T.; Kayo, C.

Sustainable Campus: Reducing

Environmental and Financial Burdens

by Using Pruned Branches for

On-Campus Energy. Sustainability

2021, 13, 7480. https://doi.org/

$10.3390 /$ su13137480

Academic Editor:

Alberto-Jesus Perea-Moreno

Received: 14 June 2021

Accepted: 2 July 2021

Published: 5 July 2021

Publisher's Note: MDPI stays neutral with regard to jurisdictional claims in published maps and institutional affiliations.

Copyright: (c) 2021 by the authors. Licensee MDPI, Basel, Switzerland. This article is an open access article distributed under the terms and conditions of the Creative Commons Attribution (CC BY) license (https:// creativecommons.org/licenses/by/ $4.0 /)$.

\begin{abstract}
Sustainability activities on university campuses are an important part of building a sustainable society. As a part of this effort, the present study quantitatively evaluated the reduction in greenhouse gas (GHG) emissions and disposal costs upon use of pruned branches for on-campus energy use in a Japanese university. The pruned branches are currently used off campus as fuel for biomass power generation, whereas the proposed systems include their on-campus use for heating through wood-chip heaters in a greenhouse or through wood stoves in buildings. The GHG balance was evaluated using a life-cycle assessment, and the cumulative costs over a 20 y period were estimated. Using pruned branches for on-campus heating was 70-180\% more effective in reducing GHG emissions than the current off-campus power generation system. Using branches for heating eliminated the emissions produced by the transportation of pruned branches off campus and had higher thermal efficiency than power generation, which was conducive to the replacement of larger quantities of fossil fuel. In addition, the payback period of the proposed systems was estimated at 2 and $4 \mathrm{y}$ for wood stove and wood-chip heater systems, respectively. For the $20 \mathrm{y}$ period, the cumulative costs can be reduced by approximately $20 \%$.
\end{abstract}

Keywords: sustainable campus; pruned branches; power generation; wood-chip heater; wood stove; fossil fuel alternative; thermal efficiency; life-cycle assessment; greenhouse gas balance; cumulative costs

\section{Introduction}

Policies to create a sustainable society are urgently needed to mitigate climate change. In this context, universities can contribute to sustainability through research, education, social collaboration, and campus development [1]. University campuses often have abundant green spaces, as well as various buildings and facilities. Therefore, sustainable campus activities are often developed in universities to help reduce greenhouse gas (GHG) emissions and other environmental burdens, and contribute to a sustainable society [2,3]. GHGs, such as carbon dioxide $\left(\mathrm{CO}_{2}\right)$, methane $\left(\mathrm{CH}_{4}\right)$, nitrous oxide $\left(\mathrm{N}_{2} \mathrm{O}\right)$, and fluorinated gases, trap heat within the Earth's atmosphere, leading to climate change.

The reduction in energy consumption and use of renewable energy are especially important to improve the sustainability of campuses [4-9]. To promote the use of renewable energy, the pruned branches produced in the green areas of campuses [10-12] can be potentially used as renewable woody biomass. 
Previous studies have investigated GHG emissions and costs associated with using woody biomass such as forestry/sawmill residues and waste wood for energy. The Manomet Center for Conservation Sciences [13] has addressed various scientific, economic, and technological issues related to the use of forest biomass for energy, including GHG emissions and costs. Several studies have assessed the life-cycle GHG emissions and reductions from the use of sawmill residues in lumber drying, power generation, and wood pellet production [14-16]. In addition, prior research has focused on the use of forestry wood and residues for power generation [17] and of beetle-killed forests for various bioenergy sources [18]. Dyjakon et al. [19] compared the relative life-cycle GHG emissions of heat production and mulching of pruning residues in apple orchards. Marchenko et al. [20] evaluated the cost of using logging and wood processing residues for electricity and heat production. These studies primarily focused on the use of woody biomass generated from industrial processes such as forestry and lumber residues.

University campuses often have abundant green spaces that generate pruned branches and other potential biomass within a social microcosm encompassing substantial student and faculty populations along with various residential, academic, and recreational facilities. Thus, a college campus represents a unique type of space within which renewable woody biomass energy from sources such as pruned branches can be locally produced and consumed. This implies that the cost of common management and disposal of such branches can be offset by their use for energy, generating economic benefits while effectively reducing GHG emissions. However, to the best of our knowledge, no study has examined the environmental and economic effects of using pruned branches for energy production on university campuses while considering the characteristics and actual conditions of such institutions. Filling this research gap is important to allow university campuses to contribute to a sustainable society.

Therefore, the objective of this study is to quantitatively evaluate the potential reduction in GHG emissions and energy costs upon use of pruned branches for the generation of energy on campus. As a study case, we investigated the Tokyo University of Agriculture and Technology campus in Japan.

The results of this study show that the use of pruned branches for heating in wood-chip heaters or wood stoves would reduce the GHG emissions of the campus by $70-180 \%$ compared with the current off-campus power generation system. The use of pruned branches for on-campus heating eliminated emissions associated with transporting branches off campus and had a higher thermal efficiency than current power generation, and the produced energy could replace energy based on fossil fuels. In addition, the payback period for the implementation of on-campus heating was estimated as $2-4 \mathrm{y}$, and the costs of power generation would be reduced by approximately $20 \%$ over $20 \mathrm{y}$. Therefore, the effective use of pruned branches on campus can reduce GHG emissions and create economic benefits. Such efforts would make university campuses more sustainable and help create awareness regarding sustainability in communities and society.

\section{Materials and Methods}

\subsection{Location}

This study was conducted at the Tokyo University of Agriculture and Technology, Faculty of Agriculture campus, which is located in Fuchu City, Tokyo and has an area of approximately $286,500 \mathrm{~m}^{2}$ [21], including abundant green space with wood and agricultural land [22] (Figure 1). The average annual energy consumption of the Fuchu campus was approximately 77,900 GJ from 2015 to 2019, and its main energy sources include grid power, municipal gas, kerosene, and diesel [23]. 


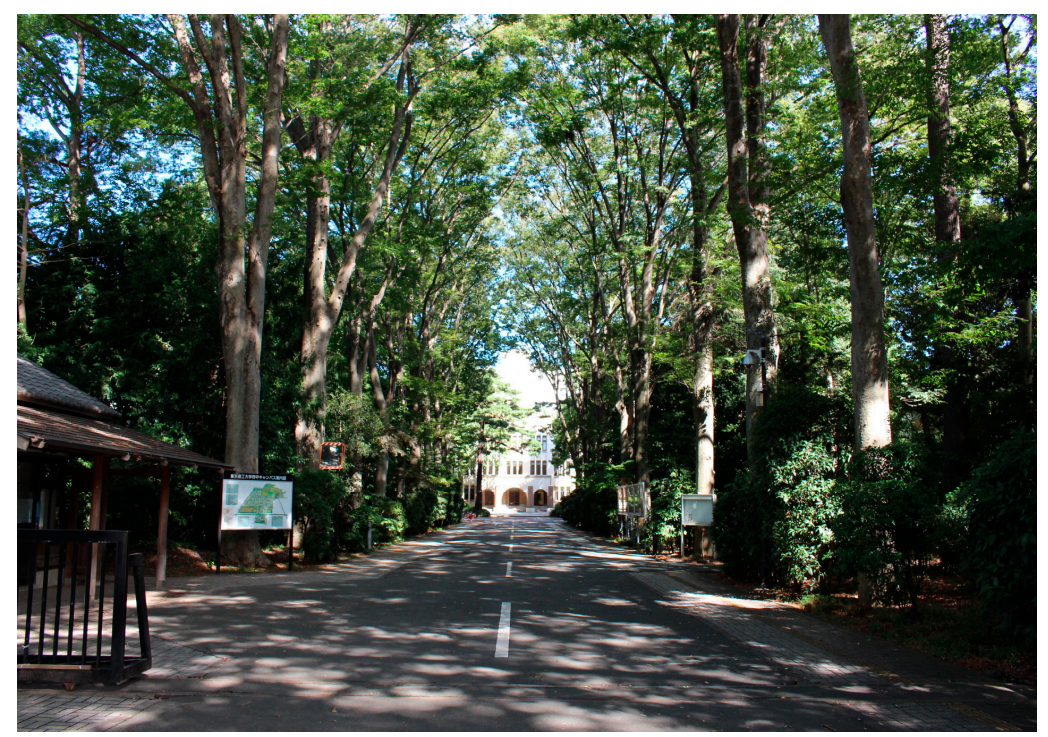

(a)

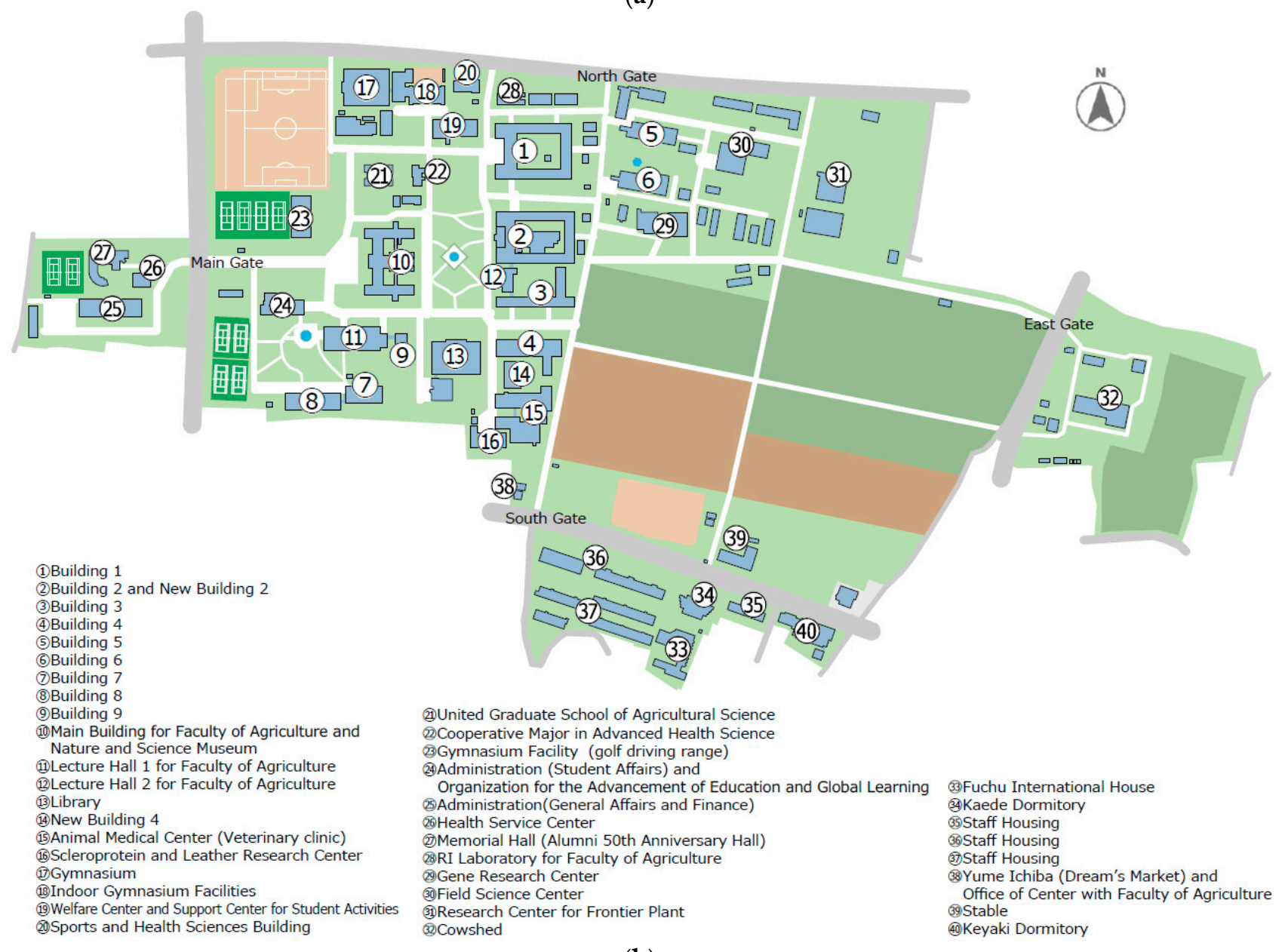

(b)

Figure 1. Tokyo University of Agriculture and Technology in Fuchu, Japan: (a) main gate; (b) campus map [22].

\subsection{Quantification of Pruned Branches and Processing Costs}

According to interviews and information collected from relevant university departments, pruning companies, and waste disposal firms, the pruning of broad-leaved trees on the Fuchu campus generated between 23,780 to $90,120 \mathrm{~kg} / \mathrm{y}$ of branches from 2010 to 
2018, with an average of 56,729 kg/y (Figure 2). Currently, these pruned branches are transported to waste processing facilities and eventually used as fuel in biomass power plants in prefectures close to Tokyo (see Section 2.3). The average yearly cost to process these pruned branches is approximately $16,612,000 \mathrm{JPY}$, of which $70 \%(11,628,000 \mathrm{JPY})$ is for pruning and $30 \%(4,984,000 \mathrm{JPY})$ for loading, transportation, and processing.

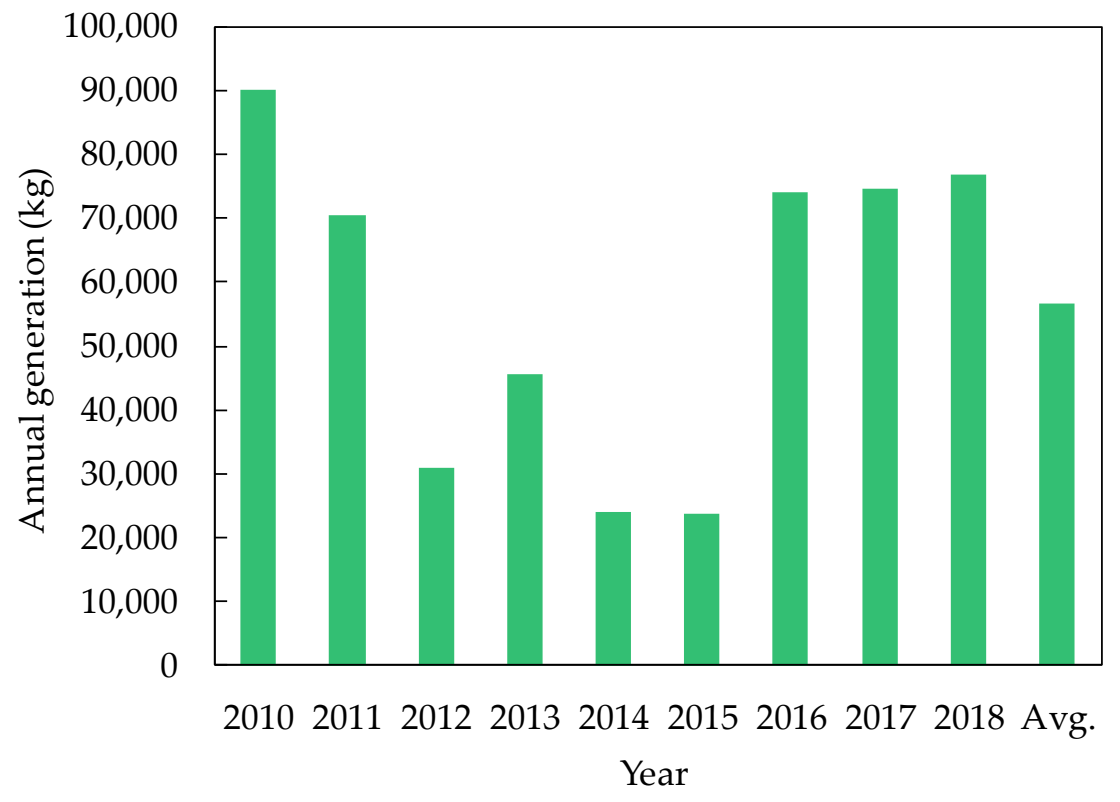

Figure 2. Annual pruned branch generation at Fuchu campus from 2010 to 2018.

\subsection{Use for Energy}

This study considers using the branches on campus for heating in wood-chip heaters in a plant research greenhouse or in wood stoves in buildings and facilities. These three energy systems (current power generation from branches, wood-chip heaters, and wood stoves) were compared with the traditional fossil fuel scenarios for the analysis.

In the current system, the trees on campus are mainly pruned by professional pruners, and the branches are temporarily stored in an on-campus collection site. The pruned branches are regularly transported from the university to a waste disposal plant in Fuchu for weighing and sorting. The pruned branches are then transported to Tokorozawa City for processing into wood chips. The processed wood chips are then distributed to eight biomass power plants in Tochigi, Ibaraki, and Kanagawa prefectures, which are close to Tokyo, to be used as fuel for power generation. Therefore, the pruned branches are used as an alternative power source in a power grid that mainly uses fossil fuels.

For the on-campus use of wood-chip heaters, the pruned branches would be processed into wood chips, dried using storage/drying sheets, and then used as fuel in the heaters in a greenhouse during the winter of the following year (November-March). Therefore, they would be an alternative to the currently used kerosene heaters. In addition, the ash generated by the burning of wood chips could be used as a soil amendment on an on-campus farm.

For use in on-campus wood stoves, the pruned branches would be dried on a vacant lot on campus using breathable flexible containers, processed into firewood, then used on campus in wood stoves of buildings and facilities during the winter of the following year (November-March). They would thus be an alternative to the current heating system that uses municipal gas as fuel. The ash generated by burning the firewood could also be used on an on-campus farm. 


\subsection{GHG Balance}

The GHG balance (emissions/reductions) of each system was determined using a life-cycle assessment (LCA) [24-26]. The functional unit was the average annual amount of pruned branches generated on campus $(56,729 \mathrm{~kg} / \mathrm{y})$. Figure 3 shows the evaluation scopes (system boundaries) of the three energy systems. Figure $3 b, c$ present on-campus wood-chip heaters and wood stoves, respectively, which were compared to the current off-campus power generation system shown in Figure 3a. As there was no available data on the manufacturing, transportation, repair, and disposal of power plants, heaters, and other equipment, these were excluded from the assessment. For each process, we examined the amounts of fossil fuel-derived GHGs $\left(\mathrm{CO}_{2}, \mathrm{CH}_{4}\right.$, and $\left.\mathrm{N}_{2} \mathrm{O}\right)$ that were emitted or reduced. Because the trees on campus are managed continuously, the $\mathrm{CO}_{2}$ generated by the burning of pruned branches was not evaluated based on the carbon-neutral concept of biomass fuel, but $\mathrm{CH}_{4}$ and $\mathrm{N}_{2} \mathrm{O}$ emissions were included in the assessments. The GHGs were converted to $\mathrm{CO}_{2}$ considering their respective 100-year global warming potential [27].

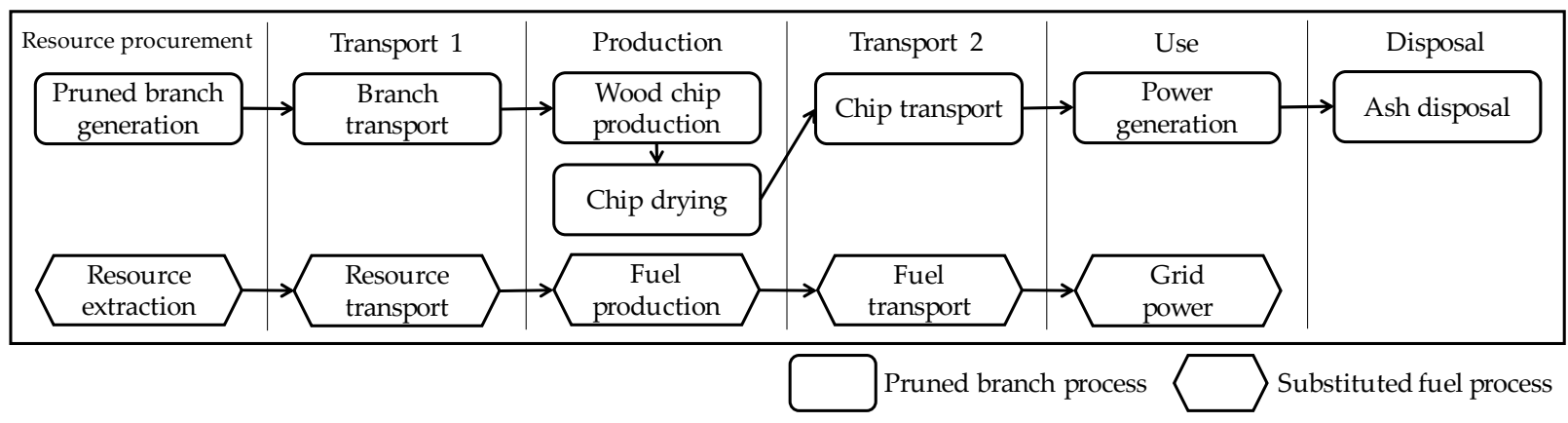

(a)

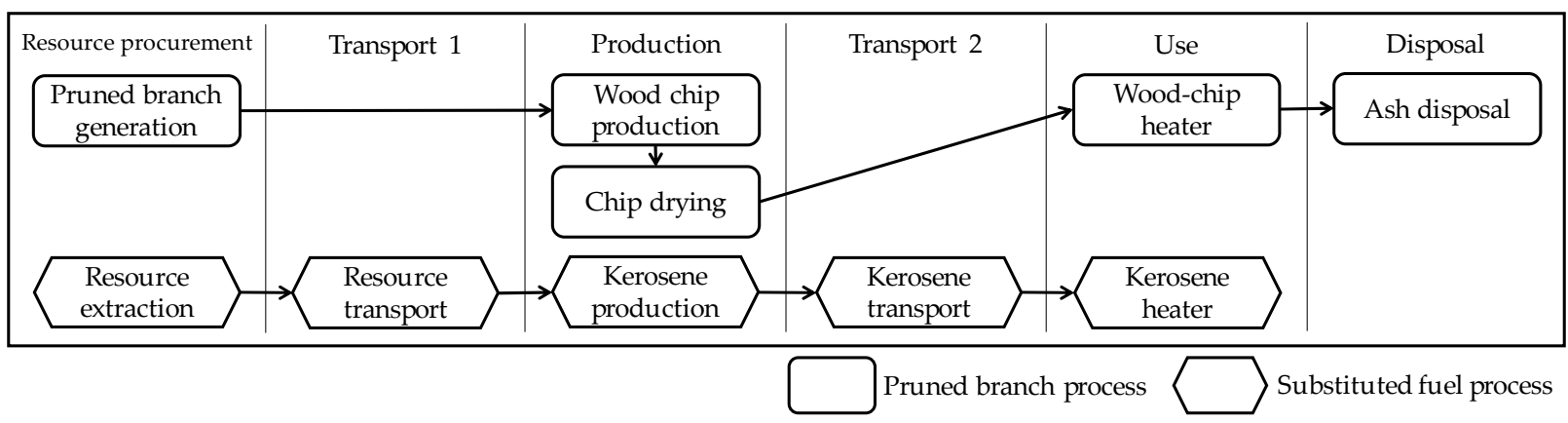

(b)

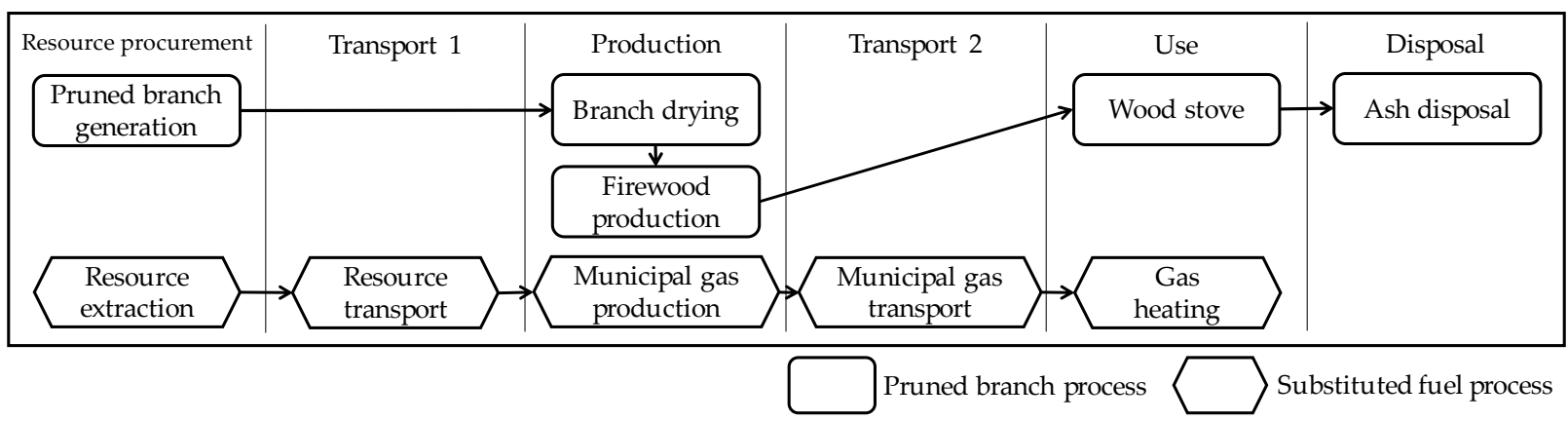

(c)

Figure 3. Life-cycle processes and system boundaries of the energy systems and their traditional fuel counterparts: (a) current off-campus power generation; (b) on-campus wood-chip heaters; (c) on-campus wood stoves. 
To evaluate the fossil fuel-derived GHG emissions and the reductions upon their substitution, we considered the distance the pruned branches and wood chips were transported, the amount of fuels used and replaced, and other factors obtained from the relevant university departments, pruners, waste disposal companies, and heating equipment manufacturers through interviews and collected numerical data (Table 1). GHG emission intensities of the fuels were mainly obtained from the Life Cycle Inventory (LCI) database Inventory Database for Environmental Analysis (IDEA) v2.1.3 [28] (Table 2). The life-cycle GHG emissions/reductions were calculated by multiplying the transportation distance and the amount of fuel used and replaced in each process (Table 1) by the corresponding GHG emission intensity (Table 2).

Table 1. Quantification of fuel use and reduction potential.

\begin{tabular}{|c|c|c|c|c|c|c|}
\hline \multicolumn{2}{|c|}{ Life-Cycle Process } & \multirow{2}{*}{$\begin{array}{l}\text { Unit } \\
\mathrm{kg}\end{array}$} & \multirow{2}{*}{$\begin{array}{c}\begin{array}{c}\text { Power } \\
\text { Generation }\end{array} \\
56,729\end{array}$} & \multirow{2}{*}{$\begin{array}{c}\begin{array}{c}\text { Wood-Chip } \\
\text { Heater }\end{array} \\
56,729\end{array}$} & \multirow{2}{*}{$\begin{array}{l}\text { Wood } \\
\text { Stove }\end{array}$} & \multirow{2}{*}{$\begin{array}{c}\text { Note } \\
1100 \mathrm{~kg} / \mathrm{m}^{3}(50 \% \text { moisture w.b.), } \\
710 \mathrm{~kg} / \mathrm{m}^{3}(20 \% \text { moisture w.b.) [29] }\end{array}$} \\
\hline $\begin{array}{l}\text { Resource } \\
\text { procurement }\end{array}$ & $\begin{array}{l}\text { Annual pruned branches } \\
\quad(50 \% \text { moisture w.b.) }\end{array}$ & & & & & \\
\hline \multirow[b]{2}{*}{ Transport 1} & $\begin{array}{c}\text { University } \\
\text { campus-disposal plant }\end{array}$ & $\mathrm{km}$ & 6.9 & - & - & $\begin{array}{l}\text { Transported } 14 \text { times in a } 4 \text {-t truck } \\
\text { (interviews with pruners) }\end{array}$ \\
\hline & Disposal plant-chip plant & $\mathrm{km}$ & 17.4 & - & - & $\begin{array}{c}\text { Transported } 14 \text { times in a } 10-\mathrm{t} \text { truck } \\
\text { (interviews with a waste disposal } \\
\text { firm) }\end{array}$ \\
\hline \multirow{4}{*}{ Production } & $\begin{array}{l}\text { Wood chips production } \\
(20 \% \text { moisture w.b.) }\end{array}$ & $\mathrm{kg}$ & 32,954 & 32,954 & - & Yield: 90\% [29] \\
\hline & $\begin{array}{l}\text { Firewood production } \\
(20 \% \text { moisture w.b. })\end{array}$ & $\mathrm{kg}$ & - & - & 32,954 & Yield: 90\% [30] \\
\hline & Diesel used by chipper & $\mathrm{L}$ & 125.2 & 125.2 & - & [29] \\
\hline & $\begin{array}{l}\text { Gasoline used by log } \\
\text { splitter }\end{array}$ & $\mathrm{L}$ & - & - & 89.6 & {$[30]$} \\
\hline Transport 2 & Chip plant-power plant & $\mathrm{km}$ & 132.6 & - & - & $\begin{array}{l}\text { Transported } 14 \text { times by } 10 \mathrm{t} \text { truck } \\
\text { (interviews with a waste disposal } \\
\text { firm), mean distance to the power } \\
\text { plants }\end{array}$ \\
\hline \multirow{2}{*}{ Use } & Power generation & MJ-LHV & 140,385 & - & - & $\begin{array}{c}\text { Thermal efficiency: } 30 \% \text { (mean of } \\
\text { values published by power plants } \\
\text { [31,32]), 14.2 MJ-LHV / kg ( } 20 \% \\
\text { moisture w.b.) [33] }\end{array}$ \\
\hline & Heating & MJ-LHV & - & 397,759 & 336,925 & $\begin{array}{c}\text { Thermal efficiency: wood chips } 85 \% \text {, } \\
\text { firewood } 72 \% \text { (interviews with } \\
\text { equipment manufacturers), } \\
\text { 14.2 MJ-LHV / kg ( } 20 \% \text { moisture } \\
\text { w.b.) [33] }\end{array}$ \\
\hline Disposal & Ash generation & $\mathrm{kg}$ & 659 & 659 & 659 & $2 \%$ generation rate \\
\hline \multirow{3}{*}{ Substitution } & $\begin{array}{l}\text { Replacement of grid } \\
\text { power }\end{array}$ & $\mathrm{kWh}$ & 38,996 & - & - & $3.6 \mathrm{MJ} / \mathrm{kWh}$ \\
\hline & Replacement of kerosene & $\mathrm{L}$ & - & 12,896 & - & $\begin{array}{l}\text { Thermal efficiency: } 90 \% \text {, } \\
\text { 34.27 MJ-LHV/L [34] }\end{array}$ \\
\hline & $\begin{array}{c}\text { Replacement of municipal } \\
\text { gas }\end{array}$ & $\mathrm{m}^{3}$ & - & - & 10,273 & $\begin{array}{l}\text { Thermal efficiency: 90\%, } \\
\text { 36.44 MJ-LHV / } \mathrm{m}^{3}[34]\end{array}$ \\
\hline
\end{tabular}


Table 2. GHG emission intensity (kg- $\mathrm{CO}_{2} \mathrm{eq} /$ unit).

\begin{tabular}{|c|c|c|c|}
\hline Life-Cycle Process & Unit & Emissions & Note \\
\hline $\begin{array}{l}\text { Transport by } 4 \text {-t truck (outbound, load rate } 100 \% \text { ) (resource } \\
\text { extraction-diesel production-diesel combustion) }\end{array}$ & $\mathrm{t} \cdot \mathrm{km}$ & 0.199 & [28] \\
\hline $\begin{array}{l}\text { Transport by } 4 \text {-t truck (return, load rate } 0 \% \text { ) (resource } \\
\text { extraction-diesel production-diesel combustion) }\end{array}$ & $\mathrm{km}$ & 1.302 & [28] \\
\hline $\begin{array}{l}\text { Transport by } 10-\mathrm{t} \text { truck (outbound, load rate } 100 \% \text { ) (resource } \\
\text { extraction-diesel production-diesel combustion) }\end{array}$ & $\mathrm{t} \cdot \mathrm{km}$ & 0.109 & [28] \\
\hline $\begin{array}{l}\text { Transport by } 10 \text {-t truck (return, load rate } 0 \% \text { ) (resource } \\
\text { extraction-diesel production-diesel combustion) }\end{array}$ & $\mathrm{km}$ & 0.712 & [28] \\
\hline Resource extraction-diesel production & $\mathrm{L}$ & 0.354 & [28] \\
\hline Diesel combustion & MJ-HHV & 0.078 & [28], 38.04 MJ-HHV/L [34] \\
\hline Resource extraction-gasoline production & $\mathrm{L}$ & 0.543 & [28] \\
\hline Gasoline combustion & MJ-HHV & 0.083 & [28], 33.36 MJ-HHV /L [34] \\
\hline Resource extraction-fuel production-grid power generation & $\mathrm{kWh}$ & 0.458 & [35] \\
\hline Resource extraction-kerosene production & $\mathrm{L}$ & 0.314 & [28] \\
\hline Kerosene combustion & MJ-HHV & 0.076 & [28], 36.49 MJ-HHV/L [34] \\
\hline $\begin{array}{l}\text { Resource extraction-municipal gas production-municipal gas } \\
\text { combustion }\end{array}$ & MJ-HHV & 0.061 & [36], 39.96 MJ-HHV / $\mathrm{m}^{3}$ [34] \\
\hline Wood combustion $\left(\mathrm{CH}_{4}\right.$ and $\left.\mathrm{N}_{2} \mathrm{O}\right)$ & MJ-HHV & 0.002 & [28], 15.8 MJ-HHV/L [33] \\
\hline Ash disposal & $\mathrm{kg}$ & 0.002 & [28] \\
\hline
\end{tabular}

In Table 1, the pruned branches were assumed to have $50 \%$ moisture by weight [29]. The transportation process in the current off-campus power generation system includes the transport of pruned branches and wood chips by truck. The traveled distance (university campus-disposal plant-chip plant) was estimated based on the road distance to each location. For the wood chip transportation to the different power plants, the mean distance considering the eight power plants was used. On-campus wood-chip heaters and wood stoves did not require off-campus transport. The wood chips and firewood produced were assumed to have $20 \%$ moisture [29], and the amount of wood chips/firewood (20\% moisture) was calculated by multiplying the amount of pruned branches (50\% moisture) by a yield of $90 \%[29,30]$ and the ratio of the density of pruned branches with $20 \%$ moisture content $\left(710 \mathrm{~kg} / \mathrm{m}^{3}\right)$ to that with $50 \%$ moisture content $\left(1100 \mathrm{~kg} / \mathrm{m}^{3}\right)$ for broad-leaved trees [29]. The fuel consumption of the wood chipper was calculated by multiplying the amount of wood chips produced by the amount of diesel used [29]. Similarly, the fuel consumption of the log splitter was calculated by multiplying the amount of firewood produced by the amount of gasoline used [30]. We assumed that no fossil fuels would be used for air-drying the pruned branches. The power generated in the current system was calculated by multiplying the amount of wood chips by the thermal efficiency of $30 \%$ [31,32] and the wood lower heating value (LHV) [33]. The heat used by the wood-chip heaters and wood stoves was also calculated by multiplying the amount of wood chips/firewood by the equipment thermal efficiency (wood-chip heater: $85 \%$; wood stove: $72 \%$ ) and the LHV [33]. For disposal, the ash generated by the current power generation system goes through waste processing, but the ash generated by the wood-chip heater and wood stoves could be used on farms within the campus, eliminating the need for waste processing. For the comparison, the generated power and used heat from wood-chip heaters and wood stoves, respectively, were converted into their equivalent use of grid power, kerosene, and municipal gas.

In Table 2, the GHG emission intensity [28,36] associated with the combustion of each fuel is shown as a numerical value based on their respective higher heating value (HHV). 
After converting the amount of fuel used and the replaced amount from the LHV (Table 1) to an HHV basis, the obtained values were multiplied by the GHG emission intensity to obtain the GHG emissions and reductions.

\subsection{Costs}

The costs of the three energy systems over 20 y were estimated. The annual cost of pruning the branches $(11,628,000 \mathrm{JPY})$ was used as the basis to calculate the costs of the new on-campus systems, and the initial equipment, operating, maintenance, and labor costs associated with introducing the wood-chip heaters and wood stoves were also included. In addition, the initial equipment, operating, and maintenance costs associated with the current kerosene heaters and municipal gas heating system that would be saved by introducing the wood-chip heaters and wood stoves were also considered. These costs were estimated based on information provided by equipment manufacturers. Table 3 shows the unit prices (including consumption tax) of all investigated items.

Table 3. Unit cost (JPY/unit) of current off-campus power generation, on-campus wood-chip heater, and on-campus wood stove energy systems.

\begin{tabular}{|c|c|c|c|c|c|}
\hline \multicolumn{3}{|c|}{ Items } & Unit & Price & Note \\
\hline \multicolumn{6}{|c|}{ Current off-campus power generation } \\
\hline Costs & \multicolumn{2}{|c|}{$\begin{array}{l}\text { Pruning, loading, transporting, } \\
\text { processing branches }\end{array}$} & $\mathrm{y}$ & $16,612,000$ & \\
\hline \multicolumn{6}{|c|}{ On-campus wood-chip heaters } \\
\hline \multirow{12}{*}{ Costs } & \multicolumn{2}{|c|}{ Pruning branches } & $\mathrm{y}$ & $11,628,000$ & \\
\hline & \multirow{6}{*}{$\begin{array}{l}\text { Initial equipment } \\
\text { purchase }\end{array}$} & Chipper & unit & $3,580,000$ & $\begin{array}{c}\text { Renewed every } 8 \text { y (interviews } \\
\text { with an equipment manufacturer) }\end{array}$ \\
\hline & & $\begin{array}{l}\text { Chip storage and } \\
\text { drying sheets }\end{array}$ & roll & 217,800 & $\begin{array}{c}\text { Renewed every } 5 \text { y (interviews } \\
\text { with an equipment manufacturer) }\end{array}$ \\
\hline & & Wood-chip heater & unit & $3,000,000$ & $\begin{array}{c}2 \text { units, renewed every } 15 \mathrm{y} \\
\text { (interviews with an equipment } \\
\text { manufacturer) }\end{array}$ \\
\hline & & Chip silo & building & $2,800,000$ & $\begin{array}{c}2 \text { buildings, renewed every } 15 \text { y } \\
\text { (interviews with an equipment } \\
\text { manufacturer) }\end{array}$ \\
\hline & & Silo hut & building & $2,000,000$ & $\begin{array}{c}\text { Renewed every } 15 \text { y (interviews } \\
\text { with an equipment manufacturer) }\end{array}$ \\
\hline & & $\begin{array}{l}\text { Installation and } \\
\text { wiring }\end{array}$ & procedure & 500,000 & \\
\hline & \multirow{5}{*}{$\begin{array}{l}\text { Operating, } \\
\text { maintenance, labor }\end{array}$} & Diesel & $\mathrm{L}$ & 115 & \\
\hline & & Blade sharpening & time & 6180 & \\
\hline & & Regular worker & person/d & 15,100 & \\
\hline & & Maintenance check & time & 30,200 & \\
\hline & & Repair fund & time & 300,000 & \\
\hline \multirow[t]{3}{*}{ Costs saved } & $\begin{array}{l}\text { Initial equipment } \\
\text { purchase }\end{array}$ & Kerosene heater & unit & 285,310 & $\begin{array}{c}2 \text { units, renewed every } 15 \mathrm{y} \\
\text { (interviews with an equipment } \\
\text { manufacturer) }\end{array}$ \\
\hline & \multirow{2}{*}{$\begin{array}{l}\text { Operating, } \\
\text { maintenance }\end{array}$} & Kerosene & $\mathrm{L}$ & 88 & \\
\hline & & Maintenance check & time & 11,500 & \\
\hline
\end{tabular}

On-campus wood stoves 
Table 3. Cont.

\begin{tabular}{|c|c|c|c|c|c|}
\hline & Items & & Unit & Price & Note \\
\hline \multirow{8}{*}{ Costs } & Pruning & oranches & $\mathrm{y}$ & $11,628,000$ & \\
\hline & \multirow{4}{*}{$\begin{array}{l}\text { Initial equipment } \\
\text { purchase }\end{array}$} & Log splitter & unit & 363,000 & $\begin{array}{c}\text { Renewed every } 7 \text { y (interviews } \\
\text { with an equipment manufacturer) }\end{array}$ \\
\hline & & $\begin{array}{l}\text { Breathable flexible } \\
\text { container }\end{array}$ & bag & 5000 & $\begin{array}{c}25 \text { bags, renewed every } 3 y \\
\text { (interviews with an equipment } \\
\text { manufacturer) }\end{array}$ \\
\hline & & Wood stove & unit & 570,000 & $\begin{array}{c}6 \text { units, renewed every } 6 y \\
\text { (interviews with an equipment } \\
\text { manufacturer) }\end{array}$ \\
\hline & & $\begin{array}{l}\text { Wood stove } \\
\text { installation }\end{array}$ & unit & 750,000 & $\begin{array}{l}6 \text { units (interviews with an } \\
\text { equipment manufacturer) }\end{array}$ \\
\hline & \multirow{3}{*}{$\begin{array}{l}\text { Operating, } \\
\text { maintenance, labor }\end{array}$} & Gasoline & $\mathrm{L}$ & 134 & \\
\hline & & Regular worker & person/d & 15,100 & \\
\hline & & Maintenance check & time & 50,000 & \\
\hline \multirow{2}{*}{ Costs saved } & \multirow{2}{*}{$\begin{array}{l}\text { Operating, } \\
\text { maintenance }\end{array}$} & Municipal gas & $\mathrm{m}^{3}$ & 65 & \\
\hline & & Maintenance check & time & 11,500 & \\
\hline
\end{tabular}

\section{Results}

\subsection{GHG Balance}

Figure 4 and Table 4 show the results of the life-cycle GHG balance of the three energy systems.

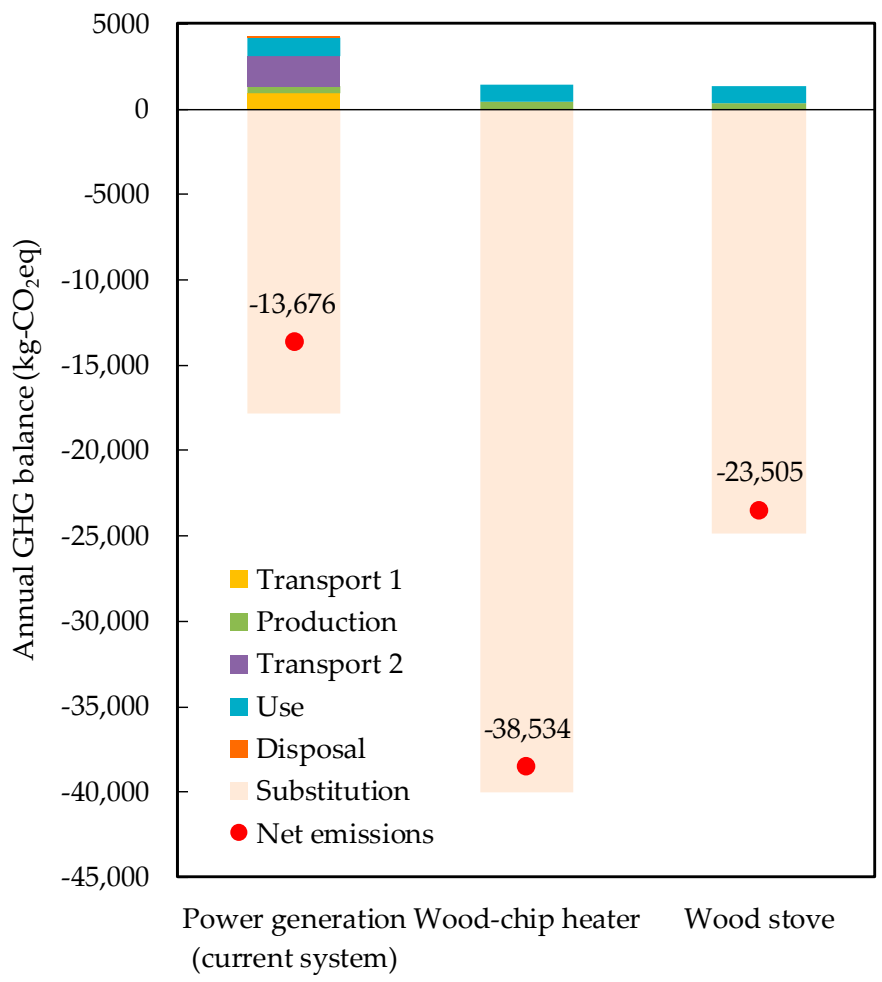

Figure 4. Annual GHG balance ( $\left.\mathrm{kg}-\mathrm{CO}_{2} \mathrm{eq}\right)$ of the energy systems. 
Table 4. Annual GHG balance (kg- $\left.\mathrm{CO}_{2} \mathrm{eq}\right)$ of the energy systems.

\begin{tabular}{cccc}
\hline Life-Cycle Process & $\begin{array}{c}\text { Power } \\
\text { Generation }\end{array}$ & $\begin{array}{c}\text { Wood-Chip } \\
\text { Heater }\end{array}$ & Wood Stove \\
\hline Transport 1 (pruned branches) & 917 & 0 & 0 \\
Production & 416 & 416 & 296 \\
Transport 2 (wood chips) & 1798 & 0 & 0 \\
Use & 1052 & 1052 & 1052 \\
Disposal & 1 & 0 & 0 \\
Substitution & $-17,860$ & $-40,002$ & $-24,853$ \\
Net emissions & $-13,676$ & $-38,534$ & $-23,505$ \\
\hline
\end{tabular}

From transport 1 to disposal, annual GHG emissions of the current, wood-chip heater, and wood stove systems were 4184, 1468, and $1348 \mathrm{~kg}-\mathrm{CO}_{2} \mathrm{eq}$, respectively. Emissions in the use stage included $\mathrm{CH}_{4}$ and $\mathrm{N}_{2} \mathrm{O}$ from the burning of wood chips or firewood. The current off-campus power generation system had the highest emissions, nearly three times the emissions of the two new systems. In the substitution process, the annual GHG reductions from the current, wood-chip heater, and wood stove energy systems were 17,860, 40,002, and $24,853 \mathrm{~kg}-\mathrm{CO}_{2} \mathrm{eq}$, respectively. The wood-chip heater system exhibited the largest reduction, which was approximately 2.2 times that of the power generation system. The net emissions considering the reductions in GHG emissions resulted in negative values or net reductions for all energy systems. The annual net reductions from the current, wood-chip heater, and wood stove systems were $13,676,38,534$, and $23,505 \mathrm{~kg}-\mathrm{CO}_{2} \mathrm{eq}(0.24,0.68$, and $0.41 \mathrm{~kg}-\mathrm{CO}_{2} \mathrm{eq} / \mathrm{kg}$-branch), respectively. Thus, the emission reduction was the smallest for the current power generation system, and the reductions from the wood-chip heater and wood stove systems were approximately $180 \%$ and $70 \%$ greater, respectively, than that of the current system.

\subsection{Costs}

Figure 5 and Table 5 display the estimated cumulative costs across $20 \mathrm{y}$ and those in year 20, respectively, for the three energy systems.

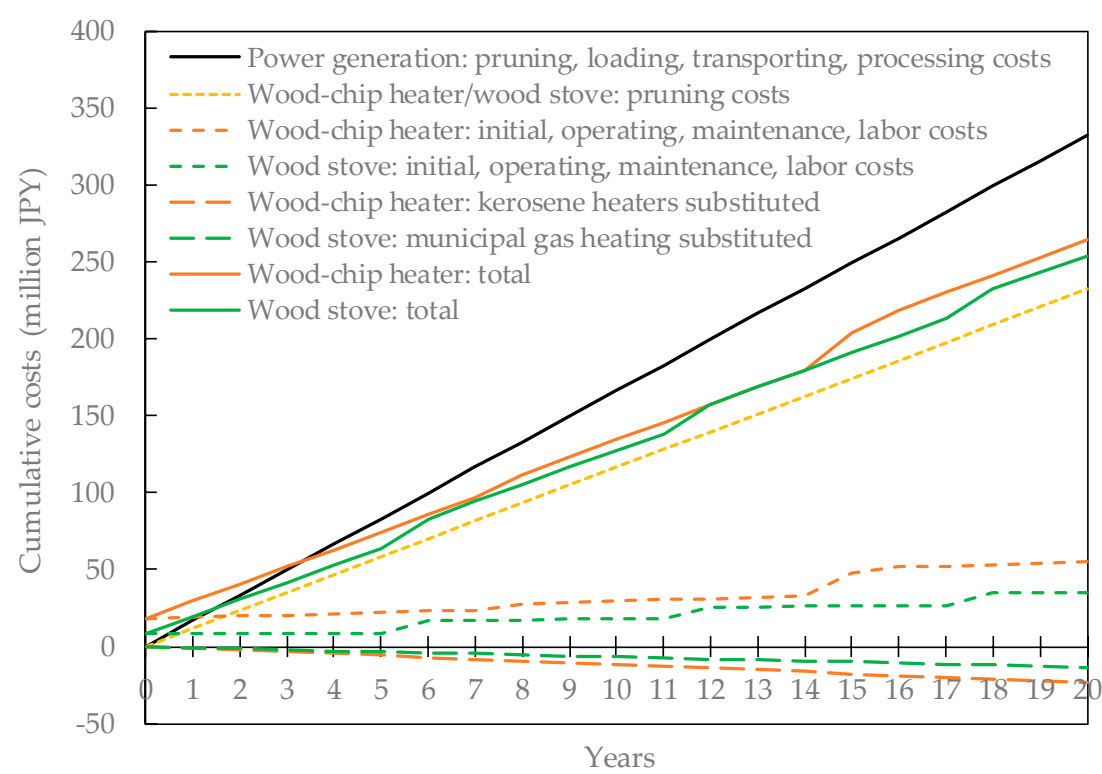

Figure 5. Cumulative costs over 20 years (million JPY). 
Table 5. Cumulative costs in year 20 (JPY).

\begin{tabular}{clrcc}
\hline & \multicolumn{1}{c}{ Items } & Power Generation & Wood-Chip Heater & Wood Stove \\
\hline \multirow{3}{*}{ Costs } & Pruning, loading, transporting, processing costs & $332,249,000$ & - & - \\
\cline { 2 - 5 } & Pruning costs & - & $232,574,000$ & $232,574,000$ \\
\cline { 2 - 5 } & Initial, operating, maintenance, labor costs & - & $-23,601,000$ & $-34,967,000$ \\
\hline \multirow{2}{*}{ Costs saved } & Kerosene heaters substituted & - & $-13,364,000$ \\
\cline { 2 - 5 } & Municipal gas heating substituted & $332,249,000$ & $263,940,000$ & $254,095,000$ \\
\hline
\end{tabular}

The estimated cost of the current off-campus power generation system over the 20 y period is approximately $332,249,000$ JPY, which includes annual costs of pruning, loading, transporting, and processing. The new on-campus wood-chip heater system has initial equipment costs (purchasing and installing a chipper, heaters, storage/drying sheets, silos, etc.) and equipment renewal costs (Table 3). In addition, after the first year, there are operating, maintenance, and labor costs associated with equipment use. However, the annual costs for loading, transporting, and processing pruned branches are no longer incurred, and only the cost of pruning the branches is maintained. In addition, this eliminates the annual operating and maintenance costs associated with the current kerosene heater, as well as renewal costs to update the respective equipment. The payback period of the wood-chip heater system is only $4 \mathrm{y}$. Thus, the cumulative cost of introducing wood-chip heaters exceeds that of the current power generation system only until year 3 , after which the former is economically superior. Over $20 \mathrm{y}$, the total expenditure of the wood-chip heater system was estimated as $263,940,000 \mathrm{JPY}$, which is approximately $21 \%$ lower than that of the current power generation system. For on-campus wood stoves, the initial costs (purchasing and installing a log splitter, breathable flexible container, and wood stoves) and renewal costs to update equipment (Table 3) are lower than those of the woodchip heater system. Operating, maintenance, and labor costs associated with the log splitter and wood stoves are incurred every year, but nothing is spent on loading, transporting, and processing of pruned branches. Moreover, the operating and maintenance costs associated with the current municipal gas heating are eliminated. The payback period of the wood stove system is only $2 \mathrm{y}$, after which the investments already generate economic value. Over $20 \mathrm{y}$, the cumulative expenditure was estimated as $254,095,000 \mathrm{JPY}$, which is approximately $24 \%$ lower than the costs of the current power generation system.

\section{Discussion}

\subsection{GHG Balance}

Of the annual GHG emissions for the current power generation system, from first transport to disposal, the transport of pruned branches and wood chips represented the largest share of emissions. Transportation accounted for approximately $65 \%$ of the total emissions (22\% from the transport of pruned branches, and $43 \%$ from the transport of wood chips) and was the main factor in the current system's higher GHG emissions when compared to those of the wood-chip heater and wood stove systems. The difference in fuel consumption between the wood chipper and the log splitter was the main factor in identifying the wood stove system as the producer of lower amounts of emissions. The emissions of the two on-campus heat uses differed by approximately $8 \%$, which is trivial compared to their respective differences with the current power generation system. In the substitution process, the difference in annual GHG reduction among these three systems was mainly attributed to the differences in thermal efficiencies and substituted fuels. While the thermal efficiency of the current power generation system is only $30 \%$, the efficiencies of the wood-chip heaters and wood stoves would be $85 \%$ and $72 \%$, respectively. This difference created a large gap in the amount of energy used (Table 1), thereby causing a major impact on the GHG emission reduction. Furthermore, the GHG emission intensity 
of the substituted fuel (which includes resource extraction, fuel production, and fuel combustion) was 0.085 and $0.061 \mathrm{~kg}-\mathrm{CO}_{2} \mathrm{eq} / \mathrm{MJ}-\mathrm{HHV}$ for kerosene and municipal gas, respectively (Table 2). The larger emissions reduction of replacing kerosene clarifies the larger emissions reduction by the wood-chip heater system. Therefore, the net life-cycle GHG reduction is higher for the use of branches in heating on campus than for the current system of power generation off campus.

Similar results were obtained in previous studies investigating the life-cycle GHG balance of woody biomass for power generation and heating [13-15], in which the emission reduction of the latter was higher than that of the former. Another study reported that the life-cycle GHG emissions of pruning residues obtained from apple orchards for heating were $15 \mathrm{~kg}-\mathrm{CO}_{2} \mathrm{eq} / \mathrm{GJ}$ [19]. This value falls in the middle range of the GHG emissions (from transport 1 to disposal) that were calculated in the present study for the current power generation, wood-chip heater, and wood stove systems as $29.8,3.7$, and $4.0 \mathrm{~kg}-\mathrm{CO}_{2} \mathrm{eq} / \mathrm{GJ}$, respectively.

A reliable supply of pruned branches is a potential issue for on-campus heating systems. Annual amounts of pruned branches varied between 23,780 and $90,120 \mathrm{~kg} / \mathrm{y}$ from 2010 to 2018 (Figure 2). Therefore, to avoid a shortage, systems and processes would be needed for maintaining stocks of pruned branches on campus or use those generated from surrounding areas.

\subsection{Sensitivity Analysis}

The results shown in Section 3.1 indicate that the transportation of pruned branches/ wood chips and the thermal efficiencies of the processes significantly affected the life-cycle GHG balance. However, the estimations were conducted based on interviews with pruners, waste disposal companies, and equipment manufacturers, as well as from publications by power plants, and thus include some degree of uncertainty. Therefore, we conducted a sensitivity analysis to consider the extent to which the results would be influenced by variations in the distance wood chips are transported and in thermal efficiency.

For wood-chip transportation, we used the mean distance to the eight power plants participating in the current system $(132.6 \mathrm{~km}$, Table 1), but the shortest distance to a plant was $73 \mathrm{~km}$ (Kanagawa Prefecture), and the longest was $190 \mathrm{~km}$ (Ibaraki Prefecture). Therefore, we performed calculations based on the shortest and longest distances. For the thermal efficiency of power generation, the $30 \%$ value was originally chosen based on the mean value of publications by power plants (Table 1). To account for possible variations, we examined efficiencies of $40 \%, 35 \%$, and $25 \%$. For the thermal efficiency of heat use, we originally used values according to equipment manufacturers (wood-chip heater: $85 \%$, wood stove: $72 \%$; Table 1 ). For the sensitivity analysis, we examined the thermal efficiency variances with five percentage points.

Table 6 shows the results of the sensitivity analysis of the annual net GHG emissions. All cases yielded a negative value or a reduction in GHG emissions. Comparing the energy systems, the best case for the current power generation system (shortest transport distance, $+10 \%$ thermal efficiency) led to a reduction of $20,438 \mathrm{~kg}-\mathrm{CO}_{2} \mathrm{eq}$, which was still smaller than the worst case for the wood-chip heaters and wood stoves $(-5 \%$ thermal efficiency) at 36,181 and $21,779 \mathrm{~kg}-\mathrm{CO}_{2} \mathrm{eq}$, respectively. According to the calculation, power generation thermal efficiency values higher than $72 \%$ and $47 \%$ are required to surpass the net GHG reduction from the wood-chip heaters and wood stoves (the current case), respectively. Furthermore, the best case for wood stoves ( $+5 \%$ thermal efficiency) led to a reduction of $25,231 \mathrm{~kg}-\mathrm{CO}_{2} \mathrm{eq}$, which was smaller than the worst case for wood-chip heaters ( $-5 \%$ thermal efficiency) at $36,181 \mathrm{~kg}-\mathrm{CO}_{2}$ eq. Therefore, the net GHG reduction was still the largest for wood-chip heaters, followed by wood stoves, and the current power generation system for all cases. These results demonstrate that using pruned branches for on-campus heating is more effective in reducing GHG than using them for off-campus power generation. 
Table 6. Sensitivity analysis of annual net GHG emissions ( $\left.\mathrm{kg}-\mathrm{CO}_{2} \mathrm{eq}\right)$.

\begin{tabular}{cccc}
\hline Case & Power Generation & Wood-Chip Heater & Wood Stove \\
\hline Current & $-13,676$ & $-38,534$ & $-23,505$ \\
Shortest transport distance & $-14,485$ & - & - \\
Longest transport distance & $-12,898$ & - & - \\
Thermal efficiency $+10 \%$ & $-19,630$ & $-40,887$ & $-25,231$ \\
Thermal efficiency $+5 \%$ & $-16,653$ & $-36,181$ & $-21,779$ \\
Thermal efficiency $-5 \%$ & $-10,700$ & - & - \\
Shortest transport distance \& & $-20,438$ & - & - \\
thermal efficiency $+10 \%$ & $-17,461$ & - & - \\
Shortest transport distance \& & & & \\
thermal efficiency $+5 \%$ & -9922 & & \\
Longest transport distance \& & & & \\
thermal efficiency $-5 \%$ & &
\end{tabular}

\subsection{Costs}

A previous study reported that the investment, operating, and maintenance costs of using wood chips and pellets for energy were higher than those associated with diesel and natural gas use [20]. The results of this study also showed that the costs of wood-chip heaters and wood stoves were greater than the eliminated costs possible as a result of replacing kerosene and municipal gas (Figure 5 and Table 5), confirming the trends observed in previous research. Although another previous study presented contradicting results, where the use of wood for heat was more expensive than that for power generation [13], the present study applied to a university campus indicates that the cost of heating from on-campus pruned branches would be lower than that for off-campus power generation. At present, pruned branches are processed as waste products that are used as fuel for power generation. Therefore, the associated costs are regarded as waste disposal costs (rather than a power generation issue), and universities have not focused on reducing such waste disposal costs. However, our results indicate that effectively shifting the off-campus processing of pruned branches to on-campus energy use could reduce these disposal costs. Because the costs described in this study are estimates, the actual costs of introducing wood-chip heaters or wood stoves could vary and should be more accurately investigated before implementation. Nevertheless, it is likely that the payback period of such systems would be only a few years. Therefore, the effective use of pruned branches in university campuses can contribute to improve both environmental and economic sustainability.

\section{Conclusions}

In this study, we quantitatively evaluated the reduction in GHG emissions and costs by using pruned branches generated on campus for energy purposes as a measure toward a more sustainable campus at Tokyo University of Agriculture and Technology in Japan.

Pruned branches are currently processed off campus by a waste disposal company and used as fuel for biomass power generation in prefectures in the Greater Tokyo Area. However, using the pruned branches on campus in wood-chip heaters in a plant research greenhouse or in wood stoves in buildings and facilities can reduce their life-cycle GHG emissions by approximately $70 \%$ compared to the current system. This is largely due to the reduction in emissions associated with the transportation of pruned branches and wood chips off campus.

The GHG reduction from replacing fossil fuels was larger for wood-chip heaters (kerosene) and wood stoves (municipal gas) than for the current power generation system (typical grid power). As a result, the net GHG reductions from the current, wood-chip heater, and wood stove systems were $0.24,0.68$, and $0.41 \mathrm{~kg}-\mathrm{CO}_{2} \mathrm{eq} / \mathrm{kg}$-branch, respectively. Thus, the smallest reduction was obtained by the current power generation, and the reductions from wood-chip heaters and wood stoves were approximately $180 \%$ and $70 \%$ larger, respectively, than that of the current system. Particularly, the thermal efficiency was 
higher for heating than for power generation, which contributed to the replacement of larger amounts of fossil fuels.

The cost of using pruned branches for on-campus heating was estimated to be lower than that for off-campus power generation. The payback period of the systems was estimated at 4 and $2 \mathrm{y}$ for the wood-chip heater and wood stove systems, respectively, and their cumulative costs over 20 y would be approximately $21 \%$ and $24 \%$, respectively, lower than that of the current power generation system.

This study shows that GHG emissions and disposal costs can be reduced by effectively using pruned branches, a biomass resource generated on campus, for sustainable purposes on university campuses. In addition to the sustainability of the campus itself, such efforts can have educational effects for the surrounding community. In the future, university campuses can work in partnership with local communities by accepting and using pruned branches generated in the surrounding area.

Author Contributions: Conceptualization, S.M., T.O., A.I. and C.K.; methodology, S.M., I.S. and C.K.; formal analysis, S.M.; investigation, S.M.; data curation, S.M., T.O., A.I. and T.H.; writing-original draft preparation, S.M.; writing—review and editing, T.O., A.I., I.S., T.H. and C.K.; visualization, S.M. and C.K.; funding acquisition, C.K. All authors have read and agreed to the published version of the manuscript.

Funding: This research was funded by the Japan Society for the Promotion of Science, grant number JP20H04384 and the Kajima Foundation Fiscal 2021 Research Grant, grant number 4.

Institutional Review Board Statement: Not applicable.

Informed Consent Statement: Not applicable.

Data Availability Statement: The data presented in this study are available on request from the corresponding author.

Acknowledgments: We would like to thank the departments of the Tokyo University of Agriculture and Technology, pruners, waste disposal companies, and equipment manufacturers for providing valuable information and data for this study.

Conflicts of Interest: The authors declare no conflict of interest.

\section{References}

1. Save, P.; Terim Cavka, B.; Froese, T. Evaluation and lessons learned from a campus as a Living Lab program to promote sustainable practices. Sustainability 2021, 13, 1739. [CrossRef]

2. International Sustainable Campus. Network. Available online: https://international-sustainable-campus-network.org/ (accessed on 10 December 2020).

3. The International Alliance of Research Universities. Available online: http://www.iaruni.org/ (accessed on 10 December 2020).

4. Yoshida, Y.; Shimoda, Y.; Ohashi, T. Strategies for a sustainable campus in Osaka University. Energy Build. 2017, 147, 1-8. [CrossRef]

5. Perea-Moreno, M.-A.; Manzano-Agugliaro, F.; Hernandez-Escobedo, Q.; Perea-Moreno, A.-J. Sustainable thermal energy generation at universities by using loquat seeds as biofuel. Sustainability 2020, 12, 2093. [CrossRef]

6. Hernandez-Escobedo, Q.; Ramirez-Jimenez, A.; Dorador-Gonzalez, J.M.; Perea-Moreno, M.-A.; Perea-Moreno, A.-J. Sustainable solar energy in Mexican universities. Case study: The national School of Higher Studies Juriquilla (UNAM). Sustainability 2020, 12, 3123. [CrossRef]

7. Garrido-Yserte, R.; Gallo-Rivera, M.-T. The potential role of stakeholders in the energy efficiency of higher education institutions. Sustainability 2020, 12, 8908. [CrossRef]

8. Dharani, R.; Balasubramonian, M.; Babu, T.S.; Nastasi, B. Load shifting and peak clipping for reducing energy consumption in an Indian university campus. Energies 2021, 14, 558. [CrossRef]

9. Hinokuma, T.; Farzaneh, H.; Shaqour, A. Techno-economic analysis of a fuzzy logic control based hybrid renewable energy system to power a university campus in Japan. Energies 2021, 14, 1960. [CrossRef]

10. Li, H.; Meng, H.; He, R.; Lei, Y.; Guo, Y.; Ernest, A.; Jombach, S.; Tian, G. Analysis of cooling and humidification effects of different coverage types in small green spaces (SGS) in the context of urban homogenization: A case of HAU campus green spaces in summer in Zhengzhou, China. Atmosphere 2020, 11, 862. [CrossRef]

11. Sharma, R.; Pradhan, L.; Kumari, M.; Bhattacharya, P. Assessment of carbon sequestration potential of tree species in amity university campus Noida. Environ. Sci. Proc. 2021, 3, 52. [CrossRef] 
12. Gülçin, D.; van den Bosch, C.C.K. Assessment of Above-ground carbon storage by urban trees using LiDAR data: The case of a university campus. Forests 2021, 12, 62. [CrossRef]

13. Manomet Center for Conservation Sciences. Biomass Sustainability and Carbon Policy Study; Manomet Center for Conservation Sciences: Plymouth, MA, USA, 2010.

14. Hitoe, K.; Hattori, N. Evaluation of green house gas emissions from sawmill residues usage for energy. Mokuzai Gakkaishi 2011, 57, 63-71. [CrossRef]

15. Puettmann, M.E.; Lippke, B. Woody biomass substitution for thermal energy at softwood lumber mills in the US Inland Northwest. For. Prod. J. 2012, 62, 273-279. [CrossRef]

16. Padilla-Rivera, A.; Barrette, J.; Blanchet, P.; Thiffault, E. Environmental performance of Eastern Canadian wood pellets as measured Through life cycle assessment. Forests 2017, 8, 352. [CrossRef]

17. Shen, X.; Kommalapati, R.R.; Huque, Z. The comparative life cycle assessment of power generation from lignocellulosic biomass. Sustainability 2015, 7, 12974-12987. [CrossRef]

18. She, J.; Chung, W.; Han, H. Economic and environmental optimization of the forest supply chain for timber and bioenergy production from beetle-killed forests in northern Colorado. Forests 2019, 10, 689. [CrossRef]

19. Dyjakon, A.; den Boer, J.; Szumny, A.; den Boer, E. Local energy use of biomass from apple orchards-An LCA study. Sustainability 2019, 11, 1604. [CrossRef]

20. Marchenko, O.; Solomin, S.; Kozlov, A.; Shamanskiy, V.; Donskoy, I. Economic efficiency assessment of using wood waste in cogeneration plants with multi-stage gasification. Appl. Sci. 2020, 10, 7600. [CrossRef]

21. Tokyo University of Agriculture and Technology. TUAT Guidebook 2020-2021. 2020. Available online: http:/ / web.tuat.ac.jp/ $\sim\{$ intl/download/2020-2021_TUAT_guidebook_en.pdf (accessed on 10 December 2020).

22. Tokyo University of Agriculture and Technology. Fuchu Campus Map. 2020. Available online: https://www.tuat.ac.jp/documents/ tuat/outline/overview/access/fuchu/campus_map/20201002fuchu_en.pdf (accessed on 10 December 2020).

23. Tokyo University of Agriculture and Technology. Environmental Report 2020. 2020. Available online: https://web.tuat.ac.jp/ $\sim\{\}$ kankyou/03/reports/report_2020.pdf (accessed on 10 December 2020).

24. International Standards Organization (ISO). Environmental Management_Life Cycle Assessment_Principles and Framework (ISO 14040); ISO: Geneva, Switzerland, 2006; Available online: https:/ /www.iso.org/standard/37456.html (accessed on 10 December 2020).

25. International Standards Organization (ISO). Environmental Management_Life Cycle Assessment_Principles and Framezork (ISO 14040), Amendment 1; ISO: Geneva, Switzerland, 2020; Available online: https:/ / www.iso.org/standard/76121.html (accessed on 10 December 2020).

26. International Standards Organization (ISO). Greenhouse Gases_Carbon Footprint of Products-Requirements and Guidelines for Quantification (ISO 14067); ISO: Geneva, Switzerland, 2018.

27. Intergovernmental Panel on Climate Change (IPCC). The physical science basis, fifth assessment report. In Climate Change; Cambridge University Press: New York, NY, USA, 2013.

28. National Institute of Advanced Industrial Science and Technology (AIST); Japan Environmental Management Association for Industry (JEMAI). LCI Database IDEA Version 2.1.3; JEMAI: Tokyo, Japan, 2017.

29. Fuchu City. Feasibility Study and Subcontracting Report on the Utilization of Pruned Branches in Fuchu City; 2020; Available online: https://www.city.fuchu.tokyo.jp/shisetu/kankyo/koen/houkokusho.files/houkokusho.pdf (accessed on 5 June 2020).

30. Japan Wood Energy Co., Ltd. 2011 Fiscal Year Woody Biomass LCA Report, Support for Environmental Impact Assessments on Using Woody Biomass, Project on Increasing the Supply of Local Wood, Forestry Agency Auxiliary Project; 2012. Available online: http:/ / mori-energy.jp/pdf/lca_hokokusho.pdf (accessed on 10 December 2020).

31. Kawasaki Biomass Co. Biomass Power Generation. Available online: http://www.keins.city.kawasaki.jp/content/ksw/4/2_3_ biomass.pdf (accessed on 10 December 2020).

32. EF-ON Inc. Biomass Power Generation. Available online: https://www.ef-on.co.jp/business/biomass / (accessed on 10 December 2020).

33. Japan Woody Bioenergy Association. Calorific Value of Wood. Available online: https://www.jwba.or.jp/woodbiomass-chipquality-standard/05/ (accessed on 10 December 2020).

34. Ministry of Economy, Trade and Industry, Agency for Natural Resources and Energy. Explanation of Standard Heating Values and Carbon Dioxide Emission Factors by Energy Source (Revision of Fiscal 2018 Edition); 2020. Available online: https://www.enecho.meti.go.jp/statistics/total_energy/pdf/stte_028.pdf (accessed on 10 December 2020).

35. TEPCO Energy Partner Inc. $\mathrm{CO}_{2}$ Emission Factor in Fiscal 2019. Available online: https://www.tepco.co.jp/ep/company/ warming/ (accessed on 10 December 2020).

36. Japan Gas Association, Life-Cycle Assessment of Municipal Gas. Available online: https://www.gas.or.jp/tokucho/ (accessed on 10 December 2020). 